\title{
Athanassopoulou, E. (Ed.), (2008). United in diversity? European integration and political cultures
}

\author{
I.B. Tauris, London, ISBN 978-1-84511-232-5
}

\author{
Virginie Mamadouh
}

Published online: 3 July 2008

(C) The Author(s) 2008

By setting a question mark behind the motto of the European Union, the title of this volume underlines the disruptive effects of cultural diversity in the functioning of a political system as the European Union. The collection of essays stems from a conference held in 2003 on the theme "Political culture(s) of Europe", the sixth symposium organised by the Eleni Nakou Foundation, this time in collaboration with ELIAMEP, the Hellenic Foundation for European and Foreign Policy. But the road between the original conference and the published volume was long and tortuous, as demonstrated by a comparison of the table of contents with the titles of the contributions on the programme of the conference organised in Copenhague in September $2003^{1}$ and even the announced table of contents of the book on the website of the publisher. ${ }^{2}$ The book eventually consists of an introduction by the editor and three parts, featuring three, five, respectively four chapters.

The notion of political culture is briefly introduced in the preface as the "basic orientations of the society's members toward their system of government and toward the acquisition, exercise, retention and transfer of political authority." The book is a timely and necessary reminder of the importance of

V. Mamadouh $(\bowtie)$

AMIDSt, University of Amsterdam, Nieuwe

Prinsengracht 130, 1018 VZ Amsterdam, The Netherlands

e-mail: v.d.mamadouh@uva.nl political culture in the functioning of any political system and aims at offering a preliminary analysis of the diversity of political cultures in the member states of the European Union and of the consequences of this diversity for European integration.

The different authors have however rather different understandings of what political cultures are. The contributors represent diverse disciplines including philosophy, political geography, political economy, political science and European politics, with a large contingent of historians. They work at universities and institutes across the EU (and beyond with one contributor based in Oslo), but predominantly in smaller member states like the Netherlands, Denmark, Ireland, Greece, Hungary and the Czech Republic; Rumania and the United Kingdom being the two exceptions.

In her introduction, Ekavi Athanassopoulou discusses the importance of political cultures for European integration. She refers to The Civic Culture, the classic study published in 1963 by Gabriel Almond and Sidney Verba, seemingly endorsing their definition of political culture as the attitudes of citizens towards the political system. In fact the contributions of the book rarely deal with individual

\footnotetext{
${ }^{1}$ http://www.eliamep.gr/eliamep/files/cts_2003-09-28_political_ programme.pdf (accessed 2 May 2008).

${ }^{2}$ Palgrave is the publisher of I.B. Taurus. http://www. palgrave-usa.com/catalog/product.aspx isbn=1845112326 (accessed 2 May 2008).
} 
attitudes, they address national political cultures as cultural institutions instead. This disjuncture between the introduction and the other chapters is misleading but not necessarily a bad thing: national political institutions, traditions and memories, are indeed a major obstacle to the emergence of a European political culture in Almond \& Verba's sense.

Athanassopoulou identifies the following issues regarding European integration and political culture: the lack of a shared European political culture, the difficulty to design common institutions that would fit the diverging visions, the differential influence of national political cultures on the integration project and the impact of the Eastward enlargement with the accession of states with a transient political culture marked by a communist past. Besides, she wonders whether national political cultures will evolve into subcultures of a European political culture.

The contributions in the volume address some of these issues but in very different ways. Unfortunately the introduction does not feature a reading guide that presents the rationale behind the selection and the ranking of the essays and there is no conclusion to evaluate, which questions have been answered, and which needs more work.

The first part of the book is entitled "Political culture and national identity in Europe". The three chapters it features, deal with European political cultures in general and their evolution in the long term. Herman van der Wusten explores the construction and the impact of myths and memories on European political cultures. Miroslav Hroch sketches a broad map of cultural differences between European macro-regions and between national political cultures, in which he looks at the impact of the Roman Empire, the Reformation, colonialism, western capitalism and nation formation. J. Peter Burgess assesses the relation between modernity and national political cultures and the implication of Ulrich Beck's theory of a risk society and a second modernity for a cosmopolitan Europe and its likely political culture.

The second part of the book features chapters analysing specific nation-states and their political cultures, but always in a comparative perspective, in a European macro-region. These are very unequal chapters. Richard Vincent Comerford assesses broadly the political cultures of five nations in Northwestern Europe: France, England and the UK, Ireland, Belgium, and the Netherlands, by a brief comparison among them regarding the state, democracy, the EU, ideology and change. Ton Nijhuis offers an insightful comparison of the German and Dutch political cultures, despite an odd starting point about the likeness between the two countries and the relatively poor treatment of the Eastern German experience.

In "Cooperation among equals" Uffe Østegaard describes the similarities and differences between the political cultures of the Nordic countries. Unlike the other chapters, this is about a macro-region-Norden, but the author also discusses the alternative notions of Scandinavia or Northern Europe-that is meaningful to the political cultures of the partaking countries, and this shared Nordic culture is under discussion too.

The remaining two chapters deal with countries with common political characteristics. James Edward Miller compares the national political culture and European integration's dilemmas of Italy, Spain, Portugal and Greece, before discussing some common aspects such as patronage, regionalism or the relation between state and church. The last chapter deals with the Balkan political culture. Alina Mungiu-Pippidi \& Andrei Pippidi compare individual opinions and perceptions in Romania, Bulgaria and Serbia, showing that the political transitions managed by the communist party or its successor parties led in these countries to "democratisation without decommunisation" and how informal practices lie behind formal reforms.

The third and final part of the book is entitled "European diversity and integration" and features contributions that deal with the impact of national political cultures on integration. In "State, linguistic and cultural diversity in Europe" John Loughlin distinguishes different types of states (the 'French', the 'Germanic' and the 'Anglo-Saxon' models) and how they deal with linguistic and cultural diversity. Unfortunately the second part of the chapter about the transformation of the state since 1945 is limited to the British case. The short chapter by George Schöpflin deals with the role of institutions in more general terms, and the importance of a European demos in the absence of a European ethnos.

The last two papers deal with money and the EMU. Loukas Tsoukalis discusses the impact of national political cultures, especially the German one, on the EMU. Erik Holm, (Director of the Eleni Nakou Foundation and initiator of the conference) explores the tension between a political system that 
respects national political cultures and a monetary union "that shows little or no respect for the economic cultures of the member states."

More than many such collections, the book lacks some cohesiveness, not because of the topics addressed but more because of the limited input of the editor to draw general conclusions. Even the referencing systems have not been harmonised between the chapters: sometimes notes, sometimes Harvard system. Fortunately there is an index.

It is disappointing that several important countries are overlooked in part 2: the Baltic states and their common experience of the Soviet state, most of Central and Eastern Europe (including Austria-a more likely candidate for comparison with Germany than the Netherlands-and Poland), as well as nonEU members Switzerland and Russia. Moreover it is unfortunate that the project neglects subnational political cultures (Catalonia, Scotland, Flanders, the
Länder of former Eastern Germany, Bavaria, the Åland islands, South Tyrol, etc.), the coexistence of subnational and national political cultures in certain member states (Belgium, Spain and the UK especially) and what could be learned from these experiences for the relation between national political cultures and an emerging European political culture.

Despite these limitations, the book offers valuable building blocks to our understanding of the diversity of political cultures in Europe (think of the contrast between Norden and Southern Europe) and represents an important step towards taking political cultures and diversity seriously.

Open Access This article is distributed under the terms of the Creative Commons Attribution Noncommercial License which permits any noncommercial use, distribution, and reproduction in any medium, provided the original author(s) and source are credited. 